\title{
The Lived Experiences of Pursuing Islamic Higher Education for People with Disabilities: Case Study at UIN Syarif Hidayatullah Jakarta
}

\author{
Luh Putu Suta Haryanthi \\ Faculty of Psychology \\ Syarif Hidayatullah State Islamic University (UIN) Jakarta \\ suta.haryanthi@uinjkt.ac.id
}

\begin{abstract}
Islamic education institutions in Indonesia are regulated under the Indonesian's Ministry of Religious Affairs. This sector contributes to approximately 30 percent of Indonesia's national educational system. While Indonesia has ratified United Nations Convention on the Rights of Person with Disabilities (UNCPRPD) in 2007 and a number of government regulations have been adopted to promote equal access for people with disabilities (PWD) for equal access to education, in reality, the practices are still far from equal. UIN Syarif Hidayatullah Jakarta, one of the leading Islamic higher educational institutions in Indonesia, has only recently started its efforts to promote an inclusive education and to provide access to PWDs. The aims of this research are to discuss the lived experiences of student with disability at UIN Jakarta. Despite the social stigma and various structural challenges, the participant manages to get into higher education. Focusing on the role of individual motivation and family supports as well as institutional supports were essential pursuing his higher education. This research relies on disabilities inclusive research methods using life-story. The experiences of student with disabilities studying at UIN is expected to contribute to the introduction and promotion of inclusive education and can be used as policy recommendation for Ministry of Religious Affairs in taking policy implementation to the rights of PWD in Islamic institutions.
\end{abstract}

Keywords: Islamic Educational Institution, People with Disabilities, Life History of PWD, Rights, Policy

\section{INTRODUCTION}

Data have shown that the prevalence of the disabled people in Indonesia were different from one to other sources. For instance, data were published by Central Bureau Statistics or in short (BPS) and Ministry of Health. Each of these institutions gave different data due to the different concept and definition which was used as a reference and an objective of the data. The data gathered from Basic Health Research defined disability as a society health condition encompassing illness and injury undergone by disability and thus influenced on the obstacle to do daily activities. Whereas the data gathered from Central Bureau Statistics (BPS) referred to the definition from National's survey of social and economy [1]. Disability, that is defined as the inability to perform an activity or certain kind of activity as normal people did, was due to the losing condition or inability related to human's ages and society. The author argue that definition stated differently by BPS and Ministry of Health caused the number of people with disability dissimilar.

Although there was diverse data gathered, yet it is clear that the number of disabled people in Indonesia rose significantly. The prevalence of people with disability based on National's survey of social and economy in 2012 revealed $2.45 \%$ from the population of Indonesia 6.640 .000 people. Disability prevalence based on educational level indicated that the higher the educational level is, the lower the disability prevalence would be. The basic educational level of disabled people was $90,56 \%$ meanwhile the equivalent of senior high school as much as $9.44 \%$. In fact, people with disability (PWD) generally has lower educational level, so that the lack of knowledge level and skill would cause a limited type of job choices. Based on the age groups, the number of PWD with productive age was that 18 to 60 years old reported as the highest group 189.364 people. Meanwhile, the numbers of PWD on productive age who had job were 56.969, and those who did not have job were 132.395 people. Data shows that the numbers of PWD who did not work were bigger than those who worked [2]. The researcher state that the number of PWD who are dominantly in the lower educational level are categorized on productive ages and unemployment. This result in PWD stays in the cycle of poverty.

The compliance of rights for PWD seems to be neglected due to the society's perspective that the disabled is an unproductive individual as well as unable to perform his/her responsibility [3]. This perspective influenced on the increasing of marginality of disabled people in Indonesia. Society is still considered PWD are those who only need to be cared not to be empowered in that society itself. That exclusive social condition is one of the factors influenced poverty due to the hindrance experienced by the disabled to be involved in economic and social activities. The researchers argue that PWD possess the equal right gaining proper education to escape from poverty.

In 2007, Indonesia ratified rights convection for the disabled people. As follow up action, Indonesian government ratified regulation No. 19 in 2011 [4]. It aims at guarantying the equal right for the disabled to fulfill their prosperity. Furthermore, Indonesian government ratified the regulation number 8 in 2016 focused on the equal right and the empowerment for the disabled by developing individual potential, hopefully PWD can optimize their roles in society. Section 10 regulation number 8 in 2016, 
stated that the disabled have rights to gain qualified education in each level either inclusively or exclusively, have the equal opportunity as an educator, and to gain proper accommodation. This is related to the regulation Number 10 in 2003 which is about National Education System in chapter 15 and 32 that emphasizes on inclusive education in primary and secondary levels [5]. The newest regulation about inclusive education is existed on Ministry of National Education Number 70 in 2009 about inclusive education as educational system organizer which provided opportunity for all the learners including PWD. The aim is that right compliance in educational aspect without any discriminatory [5]. Inclusive education is a strategy to construct inclusive culture socially in society. Besides the existence of that government's policy, it is also extensively needed some supports from relatives and societies. Regarding the existence of society's acceptance and complete supports from family, it will significantly help to build the PWD's confidence and thus it is expected to be as an optimal means in our society.

Aims of this research is describing the role of individual motivation, family supports, institutional supports and accessibility for students with disabilities pursuing higher education at Islamic higher educational institution.

\section{THEORETICAL FRAMEWORK}

Visual impairment considered as a chronic illness and categorized as disability. The effect of the emerged visual impairment is that the reluctance to exist in social situation because of the feeling of shame, fear, limitation issue in mobility due to the unavailability of supporting transportation or the existence of financial discomfort because of the limited working accessibility [6]. According to [7] there are various limitations about visual impairment disability. Personality limitation encompasses the different attitude while encountering with visual impairment people where it dominantly emerged from the feeling of mercy due to the perception of the visual impairment people as a powerless person, afraid, or lack of comfort in building relation. Sociological limitation is defined as visual impairment in which inability becomes a social role to be learned.

Stigmatization toward the people with disabilities does not only happen in Indonesia. In Croatia, stigmatization toward disability is influenced by individual perspective through both intrinsic and extrinsic elements [8]. Intrinsic element considered as a different feeling due to the result of negative attitude, prejudice and stereotype. Stigma attached intrinsically considered that disabilities are inability to make decision by themselves; the perception which based on the main characteristic is attached on individual so that it considered that disabilities are unable to express themselves. The disabled had the problem in showing the disability's ability as an expert, possessing the ability in the lower educational aspect, as well as undergoing parenting function. Whereas, extrinsic element encompassing the relation from discrimination and labeling on disabilities. Disability considered as an asexual person who is unable to take care his/her children as well as the lower self-appreciation in job field [8].

In addition, there are two difficult aspects undergone by disability namely being independent and gaining qualified job. The lack of independence in the disabled people caused the emergence of society's mythic perception that disability is a useless person that needed to be cared [7]. Visual impairment is the biggest second factor from individual who is unable to work. Even people who underwent visual impairment are often correlated with jobless and poverty. Here, independent training is needed to be conducted since the medieval childhood but then the fact is that in inclusive education, the teachers do not have sufficient time to train children's independence in their daily lives [7]. Jobless status tends to attach on adult visual impairment or improper position in their work. It correlated to the curriculum handling as well as the lack of intensive job training for them.

Visual impairment people in Canada revealed that the higher average of disability significantly placed in the number of jobless and having lower standard job. One of the obstacles is that the existence of stigmatization influenced negatively on the difficulty to access qualified job as well as to be involved in social community [9]. The researchers argued that stigmatization toward disability was influenced by the attached stereotype on the characteristics as his/her disabled identity and compared with the more dominant social group. That condition caused the emergence of labeling that disabilities are unable to perform themselves as an individual in educational aspect, having no ability and skill to build a family and have a role in building social and interpersonal relation with the opposite gender considered as an important development task in adulthood encompassing in disability. The hindrance to build interpersonal relation is influenced by stereotype related to the attach disability's characteristics, for instance as a pity individual. The previous research described that the participant was less confident to build relationship with a visual impairment disability. One of the factors that influenced the stigma was that other people's perspective which influenced on their self-esteem [10]. Yet the result of the different research revealed that the marriage satisfaction on woman who underwent visual impairment married with non-visual impairment described the highest level of satisfaction in Iran compared with the man with visual impairment disability who married with non-disability as well as the couples who did not have any visual impairment disability [11]. A person's visual impairment is not a couple's satisfaction indicator in a marriage. Visual impairment affect well on either the individual or for the family primarily related to independence function and psychological comfort [6]. It is not frequent to find the obstacles in self adjustment. The role changes in family as well as the stressful situation for family members. The expressions shown are fear, annoyance, guilty, and apprehension [6]. The disabilities fought until their psychological ability as well as dealt with social and economic changes or other situations happened in family [6]. The important factors in gaining marriage satisfaction 
in visual impairment disability are honesty, support, appreciation, and able to build positive communication with the couples.

\section{METHODOLOGY}

This research conducted by the senior and junior researchers at State Islamic University (UIN) Jakarta in collaboration with Institute for Religion, Politics, and Society (IRPS) at Australian Catholic University and Institute for Culture and Society at Western Sydney University. The methodological strategy developed in this article draws upon qualitative approach which emphasizes on social interaction with subjects of the research to gain the people's understanding. Specifically, the researchers used case study and life history along with field research. In case study method, the researchers gathered data from the community of UIN Jakarta. Meanwhile, researchers used life history method to emphasize on in-depth description from the subjects of the research in gathering understanding of the whole individual experiences.

The subjects of this research were categorized on two main groups. The first group is the community of State Islamic University (UIN) Jakarta. It consisted of the university and/or faculty leaders, staff, lecturers as well as non-disabled students. Hence the second group is the students' community who studied at State Islamic University (UIN) Jakarta or disabled alumni as well as with their relatives. Data collection which used in this article was participative observation and taking notes method. The observation was conducted by conducting participative observation to the subjects of the research. The researchers were taking notes of the key words from subjects' perceptions, emotions or behaviors to help us in understanding, recording and writing the report. The researchers also used photographs, key words, and interviews transcripts.

The procedure of this research consisted of preparation stage until data analysis. In the stage of preparation, the researchers compiled the background of research based on the phenomena and data related to it. Thus, we formulated the research problems. Researchers also reviewed many journals that related to the topic of the research especially about education of disabled people. The researchers designed interviews guideline that had been given to the subjects of the research. The questions related to the general knowledge of disabilities, social inclusion, and perception of disabled people' s rights, policies and the implementation of it, awareness of Government policies in fulfilling the disabled's rights in Islamic institutions. Field research was conducted in August until October 2016 in two groups as mentioned earlier. The communities that we had chosen were Graduate School of State of Islamic University (UIN) Jakarta. In data analysis stage, the researchers compiled data field notes from both from observational data and interviews transcripts. The data were analyzed based on data selection in thematic, conceptualities or analysis content to develop new concepts.

\section{RESULT AND DISCUSSION}

The respondent in this research is Mr. Jayadi (not the real name). He is a 40-years old visual impairment person. He comes from Sukabumi, West Java Indonesia. The data from National's survey of social and economy (Susenas) in 1995 revealed that west Java province has the biggest type of disability which was visual impairment or blindness which totaled 352,861 or about 28,9\% [3]. Even though there was declining prevalence of disability happened in West Java based on International Classification of Functioning (ICF) in 2008 compared to in 1995 , West Java province was reported as the province which has the biggest number of disabled people about 152.283 [2].

Jayadi is the ninth of ten children in his family. He underwent visual impairment since he was ten years old. Initially, he complained the decline in his visual function and hence his parent brought him to ophthalmologist around Sukabumi. Sukabumi is classified as one of the under developed area in West Java from the other 138 underdeveloped areas in Indonesia in 2013. The underdeveloped area has several characteristics which generally exist in rural areas with limited function and facilities, the lack of human resources, the low of accessibility to center of growth, the low living standard, less adequate central construction as well as the low of supporting economic infrastructure. Due to the lack of information about disease and inadequate health facilities, caused on the treatment through medical action to care his disease. Jayadi was diagnosed glaucoma and because of slow handling, it affected on the total blindness on both of his eyes.

\section{A. The Struggle in Education}

Before undergoing visual impairment, Jayadi studied at public school until $4^{\text {th }}$ grade of elementary school. However, since he underwent visual impairment, he just only stayed at home and tended to do passive activity such as: listening to music, sleeping, eating, and communicating with his family members. He felt shy and sad due to his different condition before. His parents let him stay at home because of the limited information known related to his child's education who was undergoing visual impairment at that time. According to BPS West Java, children with disability in school age reached 189.000 children or about $12 \%$, whereas, learners with disability reached 20.000 children who studied in exclusive school or known as Sekolah Luar Biasa (SLB) and 5000 children studied in inclusive school. It showed that there are so many disabled people in school age who do not study in elementary school yet.

Jayadi joined in education and rehabilitation in exclusive school (SLB) Wyata Guna Bandung. Jayadi grew his own motivation to be able to finish his study in 15 years old. By having the ability to read and arrange words when he was in primary school, Jayadi thought positively to be able to master Braille within 3 months by mastering its alphabet strategy. While he was in Wyata Guna, he was able to express his happiness emotion because he could tell jokes 
with his friends as well as he admitted his own condition. He had already realized that he was not alone to undergo blindness. At that time, he did not have any obstacles with his new environment, various cultures and religions. He felt comfortable and was able to share experiences with his other friends. Jayadi found the deep meaning of life where he found his new self-identity; he was more enthusiastic and grew to continue his life.

After graduating from exclusive school ( $S L B)$, Jayadi continued his study to secondary and senior high school at Islamic institution so called as a boarding school exactly in Tarogong Garut, West Java. He underwent his life in boarding school for 7 years with non-disabled enhancing his knowledge and social relation. He was the only one student with disability so that he was demanded to be able to adapt himself with the situation in boarding school. Formerly, the boarding school itself was not ready to admit visual impairment disability due to there would be some concerns from the teacher that they were not ready to teach visual impairment student. The leader of the boarding school was very touching in reading Abasa surah in AlQur'an which emphasized on education does not only deserve for those people who have rank and power but also we have to see that there was a visual impairment disability who came to clean up both of his heart and himself. The leader of the boarding school was afraid to be reproved by Allah if he ignored disabled student who wanted to study in his boarding school. Finally, Jayadi was accepted as the student but then he had to follow the same rule as nondisabled students. The boarding school parties participated sincerely to accompany Jayadi and without any fees professionally. The teachers gave mentoring by helping him to read the question in examination, while other students helped him to read books to study and repeat the lessons. Some teachers gave him affection score as an appreciation of his spirit in studying and thus Jayadi was able to get academic achievement. Jayadi always motivated himself to achieve his objectives. He argued that his success is a kind of his friends' success too which have contributed in efforts to get good scores. Society's acceptance and support were able to increase his confidence so that he could optimize his potential.

According to data of National's Survey of Social and Economy [2], the number of disabled people in West Java who did not continue their study was about 90.722 people, those who had education in primary school about 49.799 people, secondary school level were about 7.315 and senior high school level were 4.039. Whereas, disabled students graduated equivalent to Diploma $1 \& 2$ (D1/D2) were 97 people, D3 were 107 people, bachelor degree (S1) were about 211 people and S2/S3 level were only about 13 people. Those data showed that the number of disabled people who had higher education was decreased significantly. Jayadi had high motivation to continue his study to university by getting scholarship from his step parent. He studied Arabic Education in Islamic institution in Bandung. Both of his step parents always supported him to be able to finish his study on scheduled. Even though there has not been policy for disability under Ministry of Religion in Islamic University, the institution admitted disabilities but then they constantly followed the same regulation with other students. The lecturers offered spoken or written examination method, Jayadi only needed a partner to read and write him whenever the written test was conducted. He applied humanistic approach to his friends to help him to be his partners in learning process. Finally, he succeeded with the highest score/grade point academic (GPA) and became the fastest students in finishing his study out of other 80 students in his grade.

His intrinsic motivation to undergo a profession as an Arabic lecturer has boosted him to continue his study in the same University. He studied in Master Program for 3 years as he underwent his job as an operator officer in that Islamic institution. Currently Jayadi is undergoing his study in Doctoral degree in UIN Jakarta. Being a Doctor will be able to facilitate himself to be more useful for the behalf of society and demanded his profession as a lecturer. $\mathrm{He}$ is eager to inspire other people primarily for the disabled that they will be able to achieve their goals whenever they sincere effort in achieving the goals. Jayadi's dissertation discusses a topic of strategy to learn Arabic easily for the disabled. That idea was inspired in the first lecture of his study in Doctoral degree, his lecturer suggested him to change the disabled people's mindset that learning Arabic is no longer difficult, it is easier to learn. Whereas, the disabled people's enthusiasm to learn Arabic is relatively higher, however the availability of Braille alphabet is still limited. Jayadi has higher motivation to achieve his expectation in his study later. Although he encountered some obstacles during his study, there will be no words either to give up or to despair.

\section{B. Challenges and How to Overcome}

As a disabled, Jayadi encountered some challenges in his life. The first challenge was that when he underwent visual impairment due to his glaucoma. Initially, he was not ready to accept his visual condition. He felt extremely miserable because previously he was able to see but suddenly he underwent total visual impairment. However, he did not want to be involved in his prolonged grief, he realized that he was not the only one who underwent that visual impairment after he recognized his fellows and environment in Wyata Guna. It has sufficiently capable to overcome his emotional condition due his family's support that fight for his recovery and future. His religious values help him to change his view to be more positive in regard with his visual impairment. He perceived himself similarly with other people and constantly able to enjoy the pleasure although he could not see. Although he had social exclusion experience, Jayadi motivated himself to grow and empower other disabled people with various activities which accommodated their potential. He considered his life is useful for other people and instills positive values for other people through discussion forum, religious lecturing as well as advocacy for disability. He always instills the feeling of gratitude for God's grace.

The second challenge encountered by Jayadi was that his marriage with non-disabled person. Jayadi's wife, Mrs. Ety (not the real name) had challenges to adapt herself with her 
marriage. In the early of her marriage, his wife felt uncomfortable staying in Bandung (city center of West Java) until now because she felt lonely living further from her relatives. The concerned and inconvenient feeling emerged if she wanted to leave her children when she wanted to accompany her husband to work. Only because the different perception in encountering visual impairment disability, it has influenced that couple's communication pattern. Jayadi realized that he was unable to see expression, so that he sometimes had not an understanding related to his wife psychological needs. After 11 years getting married, finally his wife could accept that she is getting married with a disabled. His wife supports him to continue his Doctoral degree based on the expectation her husband will get more knowledge and thus the society will not isolate him.

The third challenge encountered by Jayadi was that his role as a parent, he has three sons. Jayadi has less emotional closeness with his first and second child due to some years previously he was apart from both of his wife and children. Whereas, his relation to his last son is emotionally close and his last son always ask to accompany his father to do daily activities. His first child did not believe that he has such a visual impairment disabled father, while his second child felt ashamed and frequently rejected him when his father offered to take his report at his school. Moreover, when his father was taking an ojek (a motorcycle vehicle ridden by someone) and thus he went through his second child then he did not want to greet his father and only kept silent. His second child's fellows often mocked his father's condition which has visual impairment disability so that he felt he was not accepted socially. His second child often cried. Jayadi ever thought about his expectation for being a Doctor while his visual impairment condition has been a burden for his children and he felt less meaningful for his family. Jayadi felt miserable and perceived there would be no social inclusion emergence in the community so that the children who have a disabled parent frequently underwent mocking or rejection in their family. Regarding to that problem, it motivated Jayadi to be able to facilitate visual impairment disabled so that they will be meaningful in a community. Social awareness can be started from the smallest unit of environment which is in main family, the existence of acceptance and social support from family will help to grow his confidence later.

According these findings, stigmatization toward disability is emphasized on the characteristics of disability as their own identity so that it is perceived that they are literally different, unlucky, and not priceless as a partner, parent, and their role in society. They tend to be labeled negatively and thus discrimination emerged in social interaction because they do not fulfill society's normative expectation. The existence of stigmatization toward disability influenced the lower realization on the rights owned by people with disabilities. They categorized as a marginal community or even underwent exclusion socially. Society's attitude and government regulation which accommodate equal right principle without any discrimination, and to gain the equal opportunity can be attempted through openness accessibility for PWD.

\section{CONCLUSION}

In conclusion, student with disabilities has strong personal motivation to pursue higher education so knowledge will be implicated broader to others. Due to many challenges, supports from relatives and institutions role important key to gain success. Meanwhile, promoting inclusive education based on student's experiences would be followed up by Ministry of Religion to take policy action fulfilling the rights of people with disabilities in Islamic institutions.

\section{REFERENCES}

[1] Indonesia Ministry of Health, "Indonesia Ministry of Health, 'Situasi penyandang disabilitas,' Data dan Informasi Kesehatan Semester II, 2014,’ Data dan Informasi Kesehatan Semester II, 2014.

[2] Social Department \& Surveyor Indonesia, "Social Department \& Surveyor Indonesia, Pendataan Penyandang Masalah Kesejahteraan Sosial (PMKS) dan Penyandang Cacat Berdasarkan Klasifikasi ICF, 2008, unpublish.” 2008.

[3] I. et. al., K. E.R, F. A, L. M, and S. O, "Irwanto, E.R. Kasim, A. Fransiska, M. Lusli and O. Siradj, Analisis situasi penyandang disabilitas di Indonesia, Pusat Kajian Disabilitas UI: Desk Review, November 2010," Pus. Kaji. Disabil. UI Desk Rev., 2010 .

[4] Indonesia Ministry of Law and Human Rights, "Indonesia Ministry of Law and Human Rights, 'Convention on the rights of persons with disabilities,' No. 19 Year 2011,” 2011.

[5] P. P, "P. Puspito, Article: Kebijakan pendidikan inklusi di Indonesia, August 2016.," 2016.

[6] M.-L. D, D. Materna-Lee, Visual impairment and blindness : Social and family implication, Veterans Health Initiative, pp. 25, April 2002. Veterans Health Initiative, 2002.

[7] M. F, F. Mangunsong, Psikologi dan pendidikan anak berkebutuhan khusus. University of Indonesia : LPSP3, 2009. University of Indonesia: LPSP3, 2009.

[8] B. M, M. M, and L. Z, "M. Buljevac, M. Majdak, and Z. Leutar, The stigma of disability: Croatian experiences, in Disability and Rehabilitation Journal, Vol. 34 No 9, pp. 725-732, October 2011," vol. 34, pp. 725-732, 2011.

[9] B. C, J. M, J. M, and P. R, “C. Benoit, M. Jansson, M. Jansenberger, and R. Philips, Disability stigmatization as a barrier to employment equity for legally-blind Canadians, in Disability \& Society, Vol. 28 No 7, pp. 970-983, December 2012.," vol. 28, pp. 970-983, 2012.

[10] F. C.S, G. G, A. R, and M. S.W, "C.S. Fichten, G. Goodrick, R. Amsel, and S.W. McKenzie, Reaction toward dating peers with visual impairments, in Rehabilitation Psychology APA, Vol. 36 No 3, 1991.," vol. 36, 1991.

[11] B. M, A. G.A, and A. M.S, "M. Bagherpour, G.A. Afrooz and M.S. Ahmadi, Compare the psychological basis of satisfaction in blind couples, sighted couples and blind man or woman couples, in International Journal of Fundamental Psychology and Social Science, Vol. 4 No 3, pp. 49-54, September 2014.," vol. 4, pp. 49-54, 2014 